\title{
Pregnant crack addicts in a psychiatric unit
}

\author{
Gestantes dependentes de crack em uma \\ unidade de internação psiquiátrica \\ Gabriela de Moraes Costa', Mauro Soibelman², Daniel Luís Zanchet', Patricia de Moraes Costa ${ }^{3}$, \\ Carlos Alberto Iglesias Salgado
}

\section{ABSTRACT}

Objective: In this study we aim to characterize a sample of 85 pregnant crack addicts admitted for detoxification in a psychiatric inpatient unit. Method: Cross-sectional study. Sociodemographic, clinical, obstetric and lifestyle information were evaluated. Results: Age of onset for crack use varied from 11 to 35 years (median $=21$ ). Approximately $25 \%$ of the patients smoked more than 20 crack rocks in a typical day of use (median $=10$; min-max =1-100). Tobacco (89.4\%), alcohol (63.5\%) and marijuana (51.8\%) were the drugs other than crack most currently used. Robbery was reported by 32 patients (41.2\%), imprisonment experience by 21 (24.7\%), trade of sex for money/drugs by 38 (44.7\%), home desertion by 33 (38.8\%); 15.3\% were positive for HIV, 5.9\% for HCV, 1.2\% for HBV and 8.2\% for syphilis. After

\section{Keywords}

Substance-related disorders, crack cocaine, pregnancy, sexually transmitted diseases.

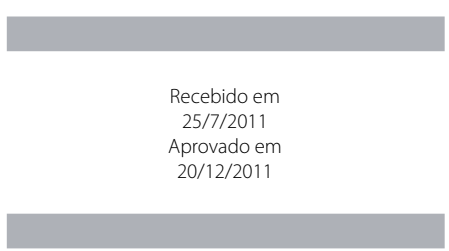

1 Universidade Federal de Ciências da Saúde de Porto Alegre (UFCSPA), Hospital Materno Infantil Presidente Vargas, Programa de Residência Médica em Psiquiatria.

2 Irmandade Santa Casa de Misericórdia de Porto Alegre (ISCMPA), Unidade de Apoio à Pesquisa.

3 Universidade Federal de Santa Maria (UFSM), Departamento de Clínica Médica.

Address for correspondence: Gabriela de Moraes Costa

Rua Professor Abílio Azambuja, 555/310

91410-130 - Porto Alegre, RS, Brasil

E-mail: gabrielademc@gmail.com 


\section{Palavras-chave}

Transtorno por uso

de substâncias,

crack, gestação,

doenças sexualmente

transmissíveis.
5,9\% (5) para HCV, 1,2\% (1) para HBV e 8,2\% (7) para sífilis. Após alta da unidade de internação psiquiátrica, somente $25 \%$ da amostra deram continuidade ao tratamento no ambulatório de dependência química. Conclusão: Comportamentos de risco para DSTs, altas taxas de HIV e síflis, elevado uso de outras drogas e envolvimento em atividades ilegais fazem parte do estilo de vida caótico dessas mulheres. Programas de prevenção e intervenção dirigidos à natureza multifatorial dessa condição precisam ser desenvolvidos.

\section{INTRODUCTION}

According to the World Drug Report 2011 cocaine use in South and Central America remains at levels higher than the global average, while Brazil has the highest number of cocaine users (900.000) in South America'. Crack addiction is a leading public health problem in Brazil. Two national household surveys about licit and illicit drug use conducted in $2001^{2}$ and $2005^{3}$ showed lifetime crack use of $0.4 \%$ and $0.7 \%$, respectively. Lifetime crack use in south Brazil was the highest in the country, increasing from $0.5 \%$ in $2001^{2}$ to $1.1 \%$ in $2005^{3}$.

The economic impact of crack addiction is not only due to the large and rapidly growing number of cases, but also to the high costs of detoxification, prolonged hospitalization, high morbidity and its association with criminality ${ }^{4}$.

Crack can influence on shaping users attitudes, values and behavior. Women who are crack addicts may affect their lives by means of difficulties in interpersonal relationships, emotional instability, violence, deprivation of schooling, economic instability and risk of HIV infection and other sexually transmitted diseases. Crack addicts, mainly women, exchange sex for drug, usually under craving ${ }^{5-7}$. Regarding sexually transmitted diseases (STD), this behavior shows that crack is not as safe as initially supposed ${ }^{8,9}$. In the meantime, many former intravenous drug users moved towards crack believing that the absence of needle-sharing would make it a safer method of administration of the drug ${ }^{8}$.

Besides all that, little is known about crack use during pregnancy, despite its potential for harming the unborn child ${ }^{10-12}$.

Therefore, our main objective is to describe pregnant crack addicts' sociodemographic and psychosocial characteristics, focusing on some associates (addictive features, comorbidities, type of psychoactive substances used, as well as trade of sex for money or drugs, robbery, home desertion and imprisonment following crack use).

\section{METHODS}

The present research is a retrospective, cross-sectional study of crack addiction during pregnancy. The research project was approved by the Research Ethics Committee of Presidente Vargas Women and Children Hospital (protocol number 24/09).
Medical chart reviews of all pregnant crack addicts admitted to detoxification from July 2006 to February 2010 in the psychiatric unit of Presidente Vargas Women and Children Hospital were conducted $(n=85)$. This hospital is a regional reference service for high risk pregnancy in Porto Alegre, Brazil. Its psychiatric unit has 24 female hospital beds, of which only up to 5 are available monthly for drug treatment.

Women selected into the study had a history of crack use during the current pregnancy, met ICD-10 criteria for cocaine/crack dependence and were heavy users (self-reported use of crack twenty or more times in the past month, according to the World Health Organization classification of drug use). The quantity of crack use was reported by the women in rocks (one rock of crack was estimated to be equivalent to 0.25 grams). Usual, maximum and minimum quantity and frequency of crack use were converted into the average number of rocks per day.

Structured interviews were conducted by medical residents in psychiatry and their supervisors during the drug treatment of these women, in the psychiatric unit. Data were collected from their medical records. Information was obtained about current and/or past (lifetime) use of a variety of other drugs: tobacco, alcohol, marijuana, solvents, inhaled cocaine, amphetamines, opiates, benzodiazepines and intravenous drugs. Demographic, lifestyle and psychological characteristics were also assessed, as well as seropositivity for HIV, hepatitis B or C, and syphilis, total number of pregnancies and history (lifetime) of perinatal death and/or major congenital malformations. Major malformations are those that have medical/social implications, often requiring surgical repair, such as: oral clefts, clubfoot, congenital heart anomalies, rectal atresia/stenosis, hip dislocation, hypospadia, spina bifida, hydrocephalus, microcephalus, anencephaly.

Furthermore, in case of referral to our outpatient service at discharge, whether or not the patient attended the consultations.

Statistical analysis was performed using the Epi Info 3.4.3, a free, public-domain software package developed by the US Centers for Disease Control. The level of significance was set at 0.05 .

Categorical variables were expressed as absolute frequencies and percents. Continuous variables were expres- 
sed as means and standard deviations or medians and amplitudes, depending on data distribution. Due to inequality of population variances (Bartelett's chi square), instead of using ANOVA procedures, statistical analysis of the association between duration of crack use (in months), as well as number of crack rocks smoked per day, robbery, imprisonment and trade of sex for money/drugs was performed using the Kruskal-Wallis $\mathrm{H}$, a non-parametric equivalent to chi square.

\section{RESULTS}

Table 1 shows sociodemographic data of the 85 pregnant crack addicts that composed the studied sample.

Table 1. Sociodemographic data of pregnant crack addicts $(n=85)$

\begin{tabular}{|c|c|c|}
\hline Variables & $\mathrm{n}$ & $\%$ \\
\hline Age (mean, SD) & 25.4 & 4.8 \\
\hline \multicolumn{3}{|l|}{ Ethnicity $(\mathrm{n}, \%)$} \\
\hline White & 34 & 40.0 \\
\hline Black & 29 & 34.1 \\
\hline Mulatto & 21 & 24.7 \\
\hline Indian & 1 & 1.2 \\
\hline Years of education (mean, SD) & 6.7 & 3.1 \\
\hline \multicolumn{3}{|l|}{ Marital status $(\mathrm{n}, \%)$} \\
\hline Single & 41 & 48.2 \\
\hline Married/living with a partner & 38 & 44.7 \\
\hline Separated/divorced & 5 & 5.9 \\
\hline Widowed & 1 & 1.2 \\
\hline \multicolumn{3}{|l|}{ Origin (n, \%) } \\
\hline Porto Alegre (city) & 56 & 67.5 \\
\hline Grande Porto Alegre (region) & 22 & 26.5 \\
\hline Other cities & 5 & 6.0 \\
\hline \multicolumn{3}{|l|}{ Ocupation $(\mathbf{n}, \%)$} \\
\hline Without ocupation & 67 & 78.8 \\
\hline Formal ocupation & 9 & 10.6 \\
\hline Informal ocupation & 9 & 10.6 \\
\hline \multicolumn{3}{|l|}{ Religion (n, \%) } \\
\hline Without religion & 42 & 49.4 \\
\hline Catholic & 28 & 32.9 \\
\hline Evangelical & 8 & 9.4 \\
\hline Spiritualist & 1 & 1.2 \\
\hline Afro-Brazilian & 6 & 7.1 \\
\hline \multicolumn{3}{|l|}{ Residence $(n, \%)$} \\
\hline Own & 8 & 9.4 \\
\hline Granted & 59 & 69.4 \\
\hline Homeless & 18 & 21.2 \\
\hline
\end{tabular}

SD: standard deviation.
The women had a median number of pregnancies of 3 (min-max $=1-12$ ). Other clinical and obstetrical data can be observed in table 2.

History of drug use (other than crack) during the current pregnancy (prenatal use) and drug use in the past (lifetime use) by the patients is available in table 3 .

More than $20 \%$ of the addicts smoked 20 or more crack rocks in a typical day of use ( median $=10$; $\min$ - $\max =1-100$ ). Age of onset of crack use varied from 11 to 35 years (min-max), with a median of 21 years old and the patients have been using crack for 2 to 101 months (median $=36$ ).

According to the patients, the main reasons to use crack (other than craving) were: sadness or stress relief (35.3\%), influence of a friend or partner who uses crack (31.8\%); easy access/availability (14.2\%).

Table 2. Clinical data of pregnant crack addicts $(n=85)$

\begin{tabular}{lcc}
\hline Variables & $\mathbf{n}$ & $\%$ \\
\hline More than one prior psychiatric hospitalization & 34 & 25.9 \\
Depressive symptoms* & 13 & 15.3 \\
Anxiety symptoms* & 16 & 18.8 \\
Psychotic symptoms* & 1 & 1.2 \\
Family history of psychiatric disorder & 59 & 70.2 \\
Use of antipsychotics* & 84 & 98.8 \\
Use of antidepressants* & 5 & 5.9 \\
Use of anticonvulsants/mood stabilizers* & 7.1 \\
Use of anxiolytics* & 6 & 2.4 \\
HIV & 2 & 15.3 \\
Hepatitis B & 13 & 1.2 \\
Hepatitis C & 1 & 17.8 \\
Syphilis & 15 & 17.6 \\
History of fetal malformation or perinatal death & 5 & 8.2 \\
Personal history of physical abuse & 7 & 15.3 \\
Personal history of moral abuse & 13 & 17.6 \\
Personal history of sexual abuse & 15 & 7.9 \\
\hline Dung hos & & \\
\hline
\end{tabular}

* During hospitalization for detoxification.

Table 3. Psychoactive drug use by patients, besides the $\operatorname{crack}(n=85)$

\begin{tabular}{lcccc}
\hline Psychoactive substances & \multicolumn{2}{c}{ Current use } & \multicolumn{2}{c}{ Use in the past } \\
\hline & $\mathbf{n}$ & $\%$ & $\mathbf{n}$ & $\%$ \\
\cline { 2 - 5 } Tobacco & 76 & 89.4 & 3 & 3.5 \\
Alcohol & 54 & 63.5 & 4 & 4.7 \\
Cannabinoids & 44 & 51.8 & 28 & 32.9 \\
Solvents & 5 & 5.9 & 12 & 14.1 \\
Inhaled cocaine & 9 & 10.6 & 41 & 48.2 \\
Amphetamines & 2 & 2.4 & 0 & 0 \\
Opiates & 0 & 0 & 0 & 0 \\
Benzodiazepines & 2 & 2.4 & 0 & 0 \\
Intravenous drug & 0 & 0 & 1 & 1.2 \\
\hline
\end{tabular}


Robbery, imprisonment experience, home desertion and trade of sex for money or drugs following crack addiction are shown in table 4.

Association between duration of crack addiction and robbery, imprisonment or trade of sex for money/drugs wasn't found. An association between robbery and number of crack rocks smoked per day was found ( $p=0.0342$ ). After discharge from the psychiatric unit, only $25 \%$ of the sample followed the proposed treatment in our hospital's outpatient unit.

Table 4. Robbery, imprisonment, home desertion and trade of sex for money/drugs, following crack addiction $(n=85)$

\begin{tabular}{lcc}
\hline \multicolumn{1}{c}{ Variables } & $\mathbf{n}$ & $\%$ \\
\hline Robbery & 35 & 41.2 \\
Imprisonment & 21 & 24.7 \\
Home desertion & 33 & 38.8 \\
Trade of sex for money/drugs & 38 & 44.7 \\
\hline
\end{tabular}

\section{DISCUSSION}

Most of the crack addicts were young (and started smoking crack early in their lives), had lower education level, were unemployed and many lived on the streets. These findings are consistent with other reports in the literature ${ }^{4,13,14}$ and with the hypothesis that, because crack is cheaper than cocaine hydrochloride (powder), it spreads in low income populations, such as the studied patients. However, these results must be analyzed with caution given the fact that the study was conducted in a public hospital. Religion practice might be a protective factor against drug addiction ${ }^{15}$ and almost half of the patients did not see themselves as religious people. Moreover, the high rates of concurrent use of other psychoactive substances (especially tobacco, alcohol and marijuana), as well as involvement in illegal activities and home desertion found in our sample are similar to those found in other researches ${ }^{16-18}$ and show their chaotic lifestyles. Nevertheless, it is particularly concerning that the pregnant women considered crack very easy to obtain and this availability might disseminate this drug in our society, as well as its devastating consequences.

Almost half of the pregnant women were single, have been pregnant three or more times and reported having traded sex for money or drugs. This suggests a link between sexual promiscuity, unplanned pregnancies and prenatal cocaine exposure. International literature documents greater risky behaviors for sexually transmitted diseases among female crack users ${ }^{7,8,19}$. In our study, HIV seroprevalence in cra$c k$ addicts was similar to the ones reported in other researches $^{20,21}$ (although these researches weren't conducted in pregnant women). An interesting fact to be added is that the risk of HIV acquisition rises during pregnancy, which might be attributable to immune responses or hormonal changes affecting the genital tract mucosa ${ }^{22}$.
A review ${ }^{23}$ of hepatitis $C$ infection among non-injection drug users found prevalence rates ranged from $2.3 \%$ to $35.3 \%$ - median of approximately $14 \%$. In our study the prevalence of HCV seropositivity was $5.9 \%$. Is worth highlighting that intravenous drug use rate (current/prenatal or in the past) was very low and this could also influence the relatively low rate of hepatitis $B$ or $C$ found in this sample. We also expected even higher rates of syphilis, considering the prevalence of trade of sex for money/drugs.

Rates of major fetal malformations and perinatal deaths in this sample are increased compared with the general population ${ }^{24}$, but the study methodology limits the conclusions that can be drawn from it. Besides, one recent study showed very few suggestions of positive associations between periconceptional illicit drug use and the occurrence of twenty birth defects categories ${ }^{25}$.

While the obstetrical impact of in utero crack exposure ${ }^{12,26}$ and pediatric impact of maternal crack use are still controversial themes, after approximately twenty years of research, not one single condition or disorder that could be labeled "crack baby" has been identified, nor is there evidence of the extent of harm that was predicted by physicians and by the media ${ }^{27}$. Singer et al. "1 reported increased risk for cognitive impairment at two years of age with prenatal cocaine exposure; meanwhile, recent cohort studies reported less frequent perinatal consequences of maternal cocaine use than the dramatic obstetrical, neonatal and developmental abnormalities reported during the 1980-90's ${ }^{10,28-30}$. Pregnant women who use crack also consume other psychoactive drugs and have very chaotic lifestyles, making it difficult to identify abnormalities caused by crack per se, even when using control groups and multivariate analysis. So, isolating the effects of crack from concomitant substance use, ethnicity, maternal age, inadequate access to medical care or poor use of health services (especially in impoverished communities) is no easy, though necessary measure to address the multifactorial nature of this problem.

The present study has several limitations. The sample, drawn from a group of women in a psychiatric inpatient unit, represents pregnant women in drug treatment rather than women from general population attending a prenatal service, hindering its generalizations. Besides, due to a number of methodological limitations, including retrospective data, lack of control group, small sample size and cross-sectional design, no inferences about cause and effect can be made.

\section{CONCLUSION}

Drug use during pregnancy is complicated by a host of additional social and medical conditions all of which may act in combination to affect the developing child. Greater risky behaviors for sexually transmitted diseases among female crack addicts, as well as high rates of maternal HIV and syphilis are significant 
findings in this report. Moreover, the high rates of concurrent use of other psychoactive substances and involvement in illegal activities contribute to show their chaotic lifestyles.

Nevertheless pregnancy provides a unique opportunity for engaging these women in specific treatments in order to provide continuity of care and achieve positive outcomes for both mother and their children, before and after birth.

\section{ACKNOWLEDGEMENTS}

The authors wish to thank Presidente Vargas Hospital staff, Dr. Ygor Arzeno Ferrão and Dr. Marcelo Moraes Victor for their contributions to the project.

\section{CONFLICT OF INTEREST}

The research project received a Research Incentive Grant (Prêmio Cyro Martins de Incentivo à Pesquisa) from Rio Grande do Sul's Psychiatric Association in 2009.

\section{REFERENCES}

1. UNODC (United Nations Office on Drugs and Crime), World Drug Report 2011 (United Nations Publication, Sales No. E.11.XI.10); 2011.

2. Carlini EA, Galduróz JC, Noto AR, Nappo AS. I levantamento domiciliar sobre o uso de drogas psicotrópicas no Brasil-2001. São Paulo: Cebrid - Centro Brasileiro de Informações sobre Drogas Psicotrópicas e Unifesp -Universidade Federal de São Paulo; 2002.

3. Carlini EA, Galduróz JC, Noto AR, Nappo AS. II levantamento domiciliar sobre 0 uso de drogas psicotrópicas no Brasil-2005. São Paulo: Cebrid - Centro Brasileiro de Informações sobre Drogas Psicotrópicas e Unifesp - Universidade Federal de São Paulo; 2006.

4. Guimarães CF, Santos DVV, Freitas RC, Araújo RB. Profile of crack users and factors related to criminality at the detoxication ward at Hospital Psiquiátrico São Pedro, Porto Alegre, Brazil. Rev Psiquiatr Rio Gd Sul. 2008;30(2):101-8.

5. Azevedo RCS, Botega NJ, Guimarães LAM. Crack users, sexual behavior and risk of HIV infection. Rev Bras Psiquiatr. 2007;29(1):26-30.

6. Malta M, Monteiro S, Lima RMJ, Bauken S, Marco A, Zuim GC, et al. HIV/AIDS risk among female sex workers who use crack in Southern Brazil. Rev Saude Publica. 2008;42(5):830-7.

7. Booth RE, Kwiatkowski CF, Chitwood DD. Sex related HIV risk behaviors: differential risks among injection drug users, crack smokers and injection drug users who smoke crack. Drug Alcohol Depend. 2000;58(3):219-26.

8. DeBeckK, Kerr T, Li K, Fischer B, Buxton J, Montaner J, et al. Smoking of crack cocaine as a risk factor for HIV infection among people who use injection drugs. CMAJ. 2009;181(9):585-9.

9. Nappo SA, Sanchez ZVM, Oliveira LG, Santos SA, Coradete JJ, Pacc JCB, et al. Comportamento de risco de mulheres usuárias de crack em relação às DST/AIDS - São Paulo: Cebrid - Centro Brasileiro de Informações sobre Drogas Psicotrópicas; 2004.
10. Frank DA, Augustyn M, Knight WG, Pell T, Zuckerman B. Growth, development and behavior in early childhood following prenatal cocaine exposure: a systematic review. JAMA. 2001;285:1613-25.

11. Singer LT, Arendt R, Minnes S, Farkas K, Salvator A, Kirchner HL, et al. Cognitive and motor outcomes of cocaine-exposed infants. JAMA. 2002;287(15):1952-60.

12. Huestis MA, Choo RE. Drug abuse's smallest victims: in utero drug exposure. Forensic Sci Int. 2002;128(1-2):20-30.

13. Dunn J, Laranjeira R. Cocaine: profiles, drug histories and patterns of use of patients from Brazil. Subst Use Misuse. 1999;34(11):1527-48.

14. Mitsuhiro SS, Chalem E, Barros MCM, Guinsburg R, Laranjeira R. Prevalence of cocaine and marijuana use in the last trimester of adolescent pregnancy: sociodemographic, psychosocial and behavioral characteristics. Addict Behav. 2007;32:392-7.

15. Kendler KS, Gardner CO, Prescott CA. Religion, psychopathology and substance use and abuse: a multimeasure, genetic-epidemiologic study. Am J Psychiatry. 1997;154:322-9.

16. Havens JR, Simmons LA, Shannon LM, Hansen WF. Factors associated with substance use during pregnancy: results from a national sample. Drug Alcohol Depend. 2009;99(1-3):89-95.

17. Sanchez ZVM, Nappo SA. Progression on drug use and its intervening factors among crack users. Rev Saude Publica. 2002;36(4):420-30.

18. Dunn J, Laranjeira R. The development of a structured interview to evaluate cocaine use and risk behavior. Rev Bras Psiquiatr. 2000;22(1):11-6.

19. Von Diemen L, De Boni R, Kessler F, Benzano D, Pechansky F. Risk behaviors for HCV and HIV-seroprevalence among female crack users in Porto Alegre, Brazil. Arch Womens Ment Health. 2010;13:185-91.

20. Ross MW, Hwang LY, Leonard L, Teng M, Duncan L. Sexual behavior, STDs and drug use in a crack house population. Int J STD AIDS. 1999;10(4):224-30.

21. McCoy CB, Lai S, Metsch LR, Messiah SE, Zhao W. Injection drug use and crack cocaine smoking: independent and dual risk behaviors for HIV infection. Ann Epidemiol. 2004;14(8):535-42.

22. Gray RH, Li X, Kigozi G, Serwadda D, Brahmbhatt H, Wabwire-Mangen F, et al. Increased risk of incident HIV during pregnancy in Rakai, Uganda: a prospective study. Lancet. 2005;366(9492):1182-8.

23. Scheinmann $R$, Hagan $H$, Weinberger $L C$, Stern $R$, Des Jarlais DC, Flom PL, et al. Non-injection drug use and hepatitis ( virus: a systematic review. Drug Alcohol Depend. 2007;89(1):1-12

24. Canfield MA, Honein MA, Yuskiv N, Xing J, Mai CT, Collins JS, et al. National estimates and race/ethnic-specific variation of selected birth defects in the United States, 1999-2001. Birth Defects Res A Clin Mol Teratol. 2006;76(11):747-56.

25. Van Gelder MM, Reefhuis J, Caton AR, Werler MM, Druschel CM, Roeleveld N; National birth defects prevention study. Maternal periconceptional illicit drug use and the risk of congenital malformations. Epidemiology. 2009;20(1):60-6.

26. Rozenak D, Diamant YZ, Yaffe H, Hornstein E. Cocaine: maternal use during pregnancy and its effects on the mother, the fetus and the infant. Obstet Gynecol Survey. 1990;45:348-59.

27. Lewis D. We were wrong about "crack babies": are we repeating our mistake with "meth babies"? Med Gen Med. 2005;7(4):30.

28. Lejeune C, Simonpoli AM, Gressens P. Obstetrical and pediatric impact of in utero cocaine exposure. Arch Pediatr. 2009;16(1):56-63.

29. Bandstra ES, Morrow CE, Mansoor E, Accornero VH. Prenatal drug exposure: infant and toddler outcomes. J Addict Dis. 2010;29(2):245-58.

30. Richardson GA, Goldschmidt $L$, Willford J. The effects of prenatal cocaine use on infant development. Neurotoxicol Teratol. 2008;30(2):96-106. 